Analysis of historical facts shows that neither a state expansion, nor economic and, the more so, political reasons can explain this phenomenon.

There was suggested a version, at a level of hypothesis, that the given movement was caused by Providencial tasks facing the Russian ethnos on the threshold of a global ecological catastrophy of the 20th-21st centuries.

On closer examination, the spiritual level of 26 peoples inhabiting the remote region is at a level which surpasses a standard European level.

Their ethnic age, according to certain data, can be estimated as 5-6 thousand years (in comparison with 2-3 thousand years for leading European ethnoses). One can suggest that at. a certain stage of their development, they have already experienced our present period of a maximum satisfaction of demands, and facing a threat of an ecological catastrophy, have brought their way of life and their number in conformity with the resources of the territory.

It is this psychological experience of comprehension that has been retained in the genetic memory of small Northern peoples. It is this experience that can be called a historical experience of ecological survival.

Of course, the like knowledge is kept by practically all the ethnoses, but with Northern peoples, because of the specific conditions of their existence and their way of life, these factors are manifested most vividly.

It is quite probable that the Russian ethnos faces a global task: having been retaining such a.n invaluable experience over 300 years, to adopt it, to comprehend it in the new conditions, on the treshold of the third millennium, to "translate» it into a conventional language and to make it a property of all the mankind (of course, not forgetting about a sad British legend of a heather honey).

The School of Ecological Survival (Yekaterinburg) has an 11 years experience of training groups of students with a European mentality, an it offers its findings for study.

\title{
CULTURE AND ENTREPRENEURSHIP
}

Irbit is the most remote town in our trip $(240 \mathrm{~km}$ away from Yekaterinburg), situated on the eastern slope of the Ural mountains, and 
farther - boundless Siberia. In the past, this was a town of the merchant class, a centre of commerce, it was farnous by its fairs. The town has a unique plannig which makes it a world monument. In the centre, there is an original caravanserai which was able to house 100 times guests more than there were inhabitants in the town at that time.

Irbit of our days is no less famous by its plants (the ones producing motor cycles, glass, pharmaceuticals).

Culture and entrepreneurship is both a new and an old subject for Russia. The Russian history before 1912 has many names of entrepreneurs - merchants, factory-owners, millowners, - creating not only material riches of Russia but also fostering development of its spiritual culture.

In the introduction to the book " 1000 Years of Russian Entrepreneuship» O.Platonov writes: "In 1918 entrepreneurship was prohibitied on pain of death. The most important element of an economic development was withdrawn from the Russian life. For a few vers, such section of population as entrepreneurs, professional organizers of the Russian economy, to whom Russia gave birth for centuries, was eliminated. By 1920, more than 100 thousand entrepreneurs have been physically destroyed or had to emigrate.

Russia was deprived of not only professional organizers of economy; aged-old history of the Russian patronage of literature and arts which was a very important and original layer of the Russian culture was interruped. A major element of a spiritual development, a powerful moral potential of economic developmenthas disappeared from the Russian life. Relations of culture and entrepreneurship include not only financial or other kind of support rendered to culture by entrepreneurs but also a great influence exerted upon entrepreneurs by culture, forming the culture of entrepreneurship, spiritual, moral motives of entrepreneurship.

Revival of entrepreneurship in Russia means revival of interrelations and mutual influence of entrepreneurship and culture. Authors of abstracts given below, remind us of the historical experience of Russia, of how Russian entrepreneurs influenced culture and the Russian culture influenced entrepreneurs, and discuss the difficulties of revival of lost relations between culture and entrepreneurship in modern Russia. 